\title{
Predikční validita zkoušek zakončujících středoškolské vzdělávání a príijímacích testů na vysoké školy ${ }^{1}$
}

\author{
Irena Bartáková, Martin Chvál, Patrícia Martinková
}

\begin{abstract}
Abstrakt: Přhhledová studie mapuje vybrané výzkumy predikčni validity zkoušek zakončujicich středoškolské vzdéláváni a prijímacích testui na vysoké školy. Predikčni validita je düležitou vlastnosti testu a vyjadruje jeho schopnost predpovidat budouci úspěch. Mezi nejuživanějǐ́ prediktory patři právě výsledky v prijimacich testech a hodnoceni ze střednich škol, pričemž porovnáváni jejich vlivu je jednim z často diskutovaných témat. Ač existuje několik kritérii akademického úspěchu, nejčastěji je využiván studijni prüměr během prvního ročniku studia, postup do druhého ročníku nebo úspěšné dokončeni studia. Analyzované studie jsou rozděleny do kapitol podle jejich hlavního cile, od studii zaměrujicich se na středoškolské zkoušky ke studiim zjištujicim predikčni validitu prijimacich zkoušek. Dalšim kritériem řazeni je zemè piovodu dat. Samostatná část je věnována výzkumưm v České republice. Ze studii jednoznačnè vyplývá, že využití prijimacich testů i prospěchu ze středni školy je v rámci prijímacích rízeni na vysoké školy opodstatnèné. Oba tyto parametry dokáži prédpovědèt, zda student bude ve studiu úspěšny i zda studium zdárně dokončí, pričemž nejlepšich výsledkủ bývá dosaženo prí zohledněni obou téchto parametrů současnè.
\end{abstract}

Klíčová slova: predikční validita, prưmèr známek, středoškolský prospěch, prijímací testy, prediktor, akademický úspěch, prospěch na V̌̌.

\section{ÚvoD}

Počet uchazečů, kteří mají zájem o studium na vysoké škole, stále převyšuje možnosti nabídky těchto škol. Podle statistiky Ministerstva školství, mládeže a tělovýchovy (MŠMT, 2017) překračoval v akademic- kém roce 2016/2017 počet uchazečů počet přijatých o přibližně $27000 \mathrm{a} v$ akademickém roce 2010/2011, kdy počet přihlášek na vysoké školy dosáhl maxima od roku 1999, byl rozdíl mezi přihlášenými a přijatými studenty dokonce 43 000. Procentuálně byl počet přijatých studentů ovšem

\footnotetext{
${ }^{1}$ Tento text vznikl v rámci projektu Odhad psychometrických vlastností jako součást vývoje prijímacích testů podpořeném GA ČR (projekt GJ15-15856Y).
} 
podobný, a to $75 \%$, respektive $73 \%$. Poměr přihlášených a přijatých studentů kolísá v závislosti na oboru, dle údajů zveřejněných univerzitami na jejich webových stránkách pro rok 2017 byl tento poměr u některých oborů dokonce 10:1. Největší rozdíl mezi počtem přihlášených a přijatých je dlouhodobě na oborech lékařských, humanitních, pedagogických a sociálních. Naproti tomu nejmenši rozdíl je na oborech technických.

Výběr studentů lze založit na různých kritériích, jakými jsou např. výsledky testů studijních předpokladů, znalostní přijímací testy či výsledky ze střední školy. Jelikož výzkum predikční validity nástrojů přijímacího řízení je nejobsáhlejší v USA, zmíníme zde průzkum americké organizace NACAC (National Association for College Admission Counseling) z roku 2016, kterého se účastnilo 424 vysokoškolských institucí. Z jeho výsledků vyplývá, že $78 \%$ těchto institucí vyžaduje testy SAT (Scholastic Aptitude Test) nebo ACT (American College Testing). ${ }^{2}$ Středoškolské výsledky jsou využívány $\mathrm{v}$ podobě středoškolského průměru či hodnocení závěrečných zkoušek. Důvěra v tyto různé druhy informací o uchazečích se liší. Zastánci prijímacích testů se opírají o fakt, že nelze objektivně srovnávat výsledky z různých škol, nebot jejich informační hodnota není srovnatel- ná. $\mathrm{Na}$ druhé straně odpůrci prìímacích testů upozorňují na skutečnost, že přijímací testy jako SAT nevypovídají dostatečně o znalostech studentů a tudíž ani připravenosti ke studiu. Zjištují momentální výkon studenta, zatímco známky ze střední školy vypovídají o dlouhodobých výkonech studenta $\mathrm{v}$ mnoha předmětech. Alternativu někteří shledávají $\mathrm{v}$ tzv. achievement tests, testech zaměřujících se na konkrétní předměty jako ACT, AP (Advanced Placement) zkoušky ${ }^{3}$ či předmětové testy SAT. V práci, která mapuje príijímací zkoušky na americké vysoké školy (Evans, 2015), se uvádí, že právě z výše zmíněných důvodů některé vysoké školy úplně ustoupily od používání přijímacích testů a praktikují celostní prrístup k uchazečům. Hodnocení tak probíhá na základě doporučujících dopisů, esejů a někdy i pohovorů s uchazeči. Tento prrístup bohužel nelze používat na všech školách, zejména na těch $s$ velkým počtem uchazečů. Praktická stránka takového přístupu je totiž značně náročná a pro některé školy by bylo komplikované posuzovat každého uchazeče individuálně. Přijímací testy tedy nadále používají zejména pro prvotní „prosetí" uchazečù.

Vhodnost jednotlivých nástrojů a kritérií se může lišit podle oborů či populace studentů, a proto je důležité zjištovat jejich predikční validitu. V České republice jsou

\footnotetext{
${ }^{2}$ Oba tyto standardizované testy jsou využívány vysokými školami k posouzení připravenosti studentů ke studiu. SAT se skládá ze tří povinných částí, kterými jsou čtení, psaní a matematika. K tomu si mohou studenti zvolit ještě esej, která je založena na porozumění danému textu. Esej mohou psát i studenti, kteří skládají ACT, povinnými částmi tohoto testu jsou angličtina, matematika, čtení a prírodovědní část.

${ }^{3}$ AP zkoušky vyvíjí organizace College Board, která je tvůrcem i testu SAT. Studenti je skládají vždy v květnu po roční př́ípravě a mohou si vybrat ze zhruba 30 předmětů. Zkoušky obsahují jak uzav̌rené, tak i otevřené otázky. Úspěšní studenti mohou být na základě svých výsledků přijati ke studiu na vysoké škole.
} 
validizační studie zatím spiše výjimkou a studie mapující jejich využití zcela chybí. V zahraničí existuje takových studií více, např́klad z již citované zprávy NACAC vyplývá, že $51 \%$ vysokoškolských institucí provádí validizační studie a více než polovina $\mathrm{z}$ nich tak činí každoročně. Jejich cílem je zrevidovat a zhodnotit užívaná kritéria, popř́ípadě je posléze upravit a ještě vylepšit.

Cílem této přehledové studie je prezentovat vybrané výzkumy predikční validity testů, a to zejména zkoušek zakončujících středoškolské vzdělávání. Pro tento přehled byly využity zdroje jak zahraniční, tak domácí, přičemž zahraniční převládají. Cílem je prozkoumat tyto studie a sumarizovat doporučení týkající se využití jednotlivých nástrojů přijímacích řízení. Nejpočetněǰši jsou studie pocházející z USA, kde je predikční validita testů detailně analyzována již od šedesátých let 20. století. Hlavní pozornost naší studie je nejprve zaměřena na závěrečné zkoušky na středních školách, dále jsou rozebrány přehledy výzkumů zjištujících predikční validitu príijimacích testů na vysoké školy a známek ze středních škol.

\section{Metodologie}

Pro přehledovou studii byly primárně vyhledány studie zabývající se predikční validitou závěrečných zkoušek. Nejvíce výsledků (okolo 600) v databázích Univerzity Karlovy (Portál elektronických zdrojů Univerzity Karlovy) a Web of Science vynesla klíčová slova predictive validity of final exams, $\mathrm{z}$ nich relevantních pro tuto studii bylo přibližně 30 . Při následném výběru prací byl za mezní určen rok 1995 , nebot přehledová studie validizačních studií od Burtona a Ramista (2001) zahrnuje práce končící právě v tomto roce. Vyhledány byly také relevantní publikace citované $\mathrm{v}$ těchto pracích.

Dále byly do naší studie zahrnuty vybrané práce zaměřené na zjištování predikční validity středoškolských známek a přijímacích testů na vysoké školy. Pozornost byla soustředěna na výzkumy zabývající se príijímacími zkouškami na lékařské fakulty. Zaměřili jsme se též na české studie analyzující validitu přijímacích zkoušek na české vysoké školy.

Přehledová studie tedy nakonec vychází z 41 publikací (členění dle zemí je uvedeno $\mathrm{v}$ tabulce 1). Jednotlivé studie byly rozděleny do kapitol podle jejich primárního zaměření. Přehledu validizačních studií závěrečných zkoušek na středních školách je věnována první kapitola. Pozornost je zde zaměřena na britské zkoušky A-Level, které jsou pro univerzity důležitým kritériem pro přijetí studentů, a na maturitní zkoušky ve Slovinsku a Finsku, jakožto i na americké AP zkoušky, u kterých je ale třeba podotknout, že na rozdíl od maturitních zkoušek, nejsou pro studenty povinné.

V další kapitole jsou obsaženy studie zabývající se predikční validitou přijímacích zkoušek. Zde jsou zastoupeny jak práce, které se zabývají primárně jen přijímacími zkouškami, tak i ty, které mají za cíl porovnat predikční validitu přijímacích testů a středoškolských úspěchů. $\mathrm{V}$ rámci této kapitoly jsou studie následně rozdě- 
Tab. 1. Přehled analyzovaných studií

\begin{tabular}{|c|c|c|c|c|}
\hline Stát & $\begin{array}{l}\text { Počet } \\
\text { studií }\end{array}$ & $\begin{array}{l}\text { Velikost } \\
\text { vzorku }\end{array}$ & $\begin{array}{l}\text { Analyzované } \\
\text { prediktory }\end{array}$ & $\begin{array}{c}\text { Kritéria } \\
\text { úspěšnosti }\end{array}$ \\
\hline Austrálie & 1 & 339 & přijímací zkoušky & studijní bodový průměr \\
\hline ČR & 8 & $92-2581$ & $\begin{array}{l}\text { přijímací zkoušky, SŠ } \\
\text { prospěch, maturitní známky, } \\
\text { test studijních předpokladů }\end{array}$ & $\begin{array}{c}\text { FYGPA, průměrné } \\
\text { známky v 2. a 3. ročníku, } \\
\text { CGPA }\end{array}$ \\
\hline Etiopie & 1 & 217 & $\begin{array}{c}\text { SŠ známky, přijímací } \\
\text { zkoušky }\end{array}$ & FYGPA \\
\hline Finsko & 1 & 50 & $\begin{array}{c}\text { maturitní zkouška, přijímací } \\
\text { zkoušky, inteligenční test }\end{array}$ & $\begin{array}{l}\text { GPA, počet kreditů, } \\
\text { kombinace obou kritérií }\end{array}$ \\
\hline Irsko & 1 & 56 & $\begin{array}{c}\text { maturitní zkouška, } \\
\text { přijímací zkoušky }\end{array}$ & studijní výsledky \\
\hline Jemen & 1 & 881 & HSGPA, přijímací zkoušky & FYGPA, CGPA \\
\hline Německo & 1 & 463 & HSGPA, přijímací zkoušky & $\begin{array}{l}\text { výsledky zkoušek, } \\
\text { pokračování ve studiu }\end{array}$ \\
\hline Nový Zéland & 1 & 1346 & přijímací zkoušky & studijní výsledky \\
\hline Singapur & 1 & 3371 & GRE & GPA \\
\hline Slovinsko & 1 & 1734 & $\begin{array}{c}\text { maturitní zkouška, SŠ výsledky } \\
\text { v posledním ročníku }\end{array}$ & $\begin{array}{c}\text { průměrná známka zkoušek, } \\
\text { dokončení studia }\end{array}$ \\
\hline Švýcarsko & 1 & 353 & přijímací zkoušky & zkoušky v 1. ročníku \\
\hline UK & 11 & $341-250175$ & $\begin{array}{l}\text { přijímací zkoušky, } \\
\text { A-Levels a ostatní } \\
\text { závěrečné zkoušky, UK- } \\
\text { CAT, BMAT }\end{array}$ & $\begin{array}{c}\text { nástup na VŠ, FYGPA, } \\
\text { opakování ročníku, } \\
\text { ukončení studia, druh } \\
\text { získaného titulu }\end{array}$ \\
\hline USA & 13 & $480-147999^{4}$ & $\begin{array}{c}\text { HSGPA, SAT, } \\
\text { AP zkoušky, GRE, MCAT }\end{array}$ & $\begin{array}{l}\text { FYGPA, CGPA, dokončení } \\
\text { studia, postup do } \\
\text { 2. ročníku, studijní průměr } \\
\text { v bakalárském programu }\end{array}$ \\
\hline Zimbabwe & 1 & 463 & $\begin{array}{c}\text { A-Levels, O-Levels, } \\
\text { HSGPA }\end{array}$ & studijní výsledky \\
\hline
\end{tabular}

AP-Advanced Placement $=$ zkoušky zakončujici středoškolské vzdèláni

BMAT - BioMedical Admissions Test = prijimaci test na lékařské fakulty ve Velké Británii a některých dalšich zemich

CGPA - z angl. Cumulative Grade Point Average = celkový studijni prümèr na VŠ

FYGPA - z angl. First Year Grade Point Average = studijni prümèr během 1. ročníku studia na VŠ

GPA - Grade Point Average = studijni prüměr

GRE - Graduate Record Examination = test pro prijímáni studentů do navazujicího studia po zakončení bakalárského programü na amerických univerzitách a uživaný $i$ v dalšich zemích

HSGPA - z angl. High School Grade Point Average = středoškolský studijni prümèr

MCAT-Medical College Admission Test = prijímaci test na lékařské fakulty $v$ USA a dalsích zemích

$S A T-$ Scholastic Aptitude Test = prijímaci test na americké unverzity

$\overline{{ }^{4} \text { Mezi studiemi jsou zahrnuty také meta-analýzy autorů Burton \& Ramist (2001), Kuncel, Hezlett \& Ones }}$ (2001) a Salvatori (2001) 
leny podle zemí. První podkapitola obsahuje studie pocházející z USA, nebot zde jsou nejpočetnější, druhá obsahuje studie z dalších anglosaských a evropských zemí a třetí podkapitola je zaměřena na přehled validizačních studií v ČR.

Validizační studie se zabývají také predikční validitou testů využívaných při postupu z bakalářských do navazujících programů, jako např. GRE (Graduate Record Examinations) test či MCAT (Medical College Admission Test). Těmto studiím je věnována třetí kapitola. Poslední, čtvrtá kapitola ukazuje přehled studií i $\mathrm{v}$ ostatních zemích jako Etiopie či Jemen, což dokládá, že predikční validita je důležitým tématem studovaným $\mathrm{v}$ mnoha zemích. Celkově členění obsahových kapitol reflektuje dostupné zdroje, které nejsou zastoupeny rovnoměrně naprííc tématy.

\section{PredikČNí VAlidita ZKoušEK ZAKONČUJÍCÍCH VYŠŠÍ SEKUNDÁRNÍ VZDĚLÁVÁNÍ}

Studií zaměřených na zjištování predikční validity závěrečných zkoušek nalezneme nejvíce ve Velké Británii, kde se věnuje pozornost zejména zkoušce General Certificate of Education Advanced Level, známé pod názvem A-Level. Tato zkouška uzavírá vyšší sekundární vzdělávání a pro studenty je nutným předpokladem pro príijetí na vysokou školu. Studenti zkoušku většinou skládají ze tří až pěti předmětů, v závislosti na oboru, který chtějí na vysoké škole studovat. Podle oboru mohou též studenti zjistit, jakých známek by měli u A-Levels dosáhnout, aby mohli být přijati. Čím prestižnější univerzita, tím jsou samozřejmě nároky vyšší, takže např. na University of Oxford nebo Cambridge University jsou přijímáni studenti jen $s$ prospěchem nejméně AAA. ${ }^{5}$

V britských studiích je nejčastějším kritériem úspěšnosti získání vysokoškolského titulu dle britské klasifikace, kdy nejvyšší stupeň se označuje first-class degree a druhý upper second-class degree. HEFCE (Higher Education Funding Council for Europe) vydal v roce 2014 zprávu zjištující výsledky 132000 studentů, kteř́ nastoupili ke studiu v akademickém roce 2007/2008 (HEFCE, 2014). Cílem této zprávy bylo zjistit, do jaké míry predikují známky ve středoškolských zkouškách A-Levels zisk first-class I upper second-classs degree $\mathrm{v}$ pozdějším vysokoškolském studiu. Autoři došli k závěru, že studenti s lepšími známkami z A-Levels dosahují lepších studijních výsledků. Více než $80 \%$ studentů se známkami $\mathrm{AAB}$ a lepšími získá nejvyšší titul, zatímco u známek CCC a hůře je to méně než $50 \%$. K obdobným výsledkům docházejí i další autoři, napr. Smith a Naylor (2001), McManus et al. (2003), kteř́ se soustředili na vliv A-Levels na studium na lékařských fakultách. Kromě získání titulu dokáží A-Levels předpovědět také to, zda student ukončí studium, či zda bude muset některé ročníky opakovat. Zanini a Vidal Rodeiro (2014) zjištovali

\footnotetext{
${ }^{5}$ Zkoušky A-Levels jsou hodnoceny na škále $A^{*}-E$, kde $A^{*}$ je nejvyšší známka. Studenti skládají tyto zkoušky $\mathrm{v}$ průměru ze tř́ předmětů. Pro přijetí na prestižní vysoké školy je ale někdy zapotřebí i čtyř až pěti předmětů.
} 
predikční validitu nejvyšší možné známky u A-Levels - A*. Ukázalo se, že počet takových známek měl pozitivní vliv na získání first-class nebo upper-second class degree. Vidal Rodeiro, Sutch a Zanini (2013) zjistili, že A-Levels mají vliv také na výběr oboru na vysoké škole a že studenti s průměrem A a vyšším nejčastěji navštěvovali prestižní univerzity ze skupiny Russel Group. ${ }^{6}$ Gill a Vidal Rodeiro (2014) se věnovali i dalším zkouškám, které studenti skládají na konci vyššího sekundárního studia, a to International Baccalauréat, Extended Project, Pre-U a BTEC (Business and Technology Education Council). ${ }^{7}$ Autoři docházejí k závěru, že všechny tyto zkoušky dokáží dobře predikovat budoucí akademický úspěch. Podíl studentů, kteří složili tyto zkoušky a dosáhli first-class degree, se pohybuje mezi 20,4 a 21,9\%, jen u BTEC byl nižší (9,6\%). Pro second-class degree byly výsledky ještě vyšší, a to $60,4-66,7 \%$, u BTEC 43,8\% studentů.

Predikční validita byla též zjištována u AP zkoušek, které lze skládat i v České republice. $\mathrm{V}$ zahraničí tyto zkoušky mnoho vysokých škol vnímá jako jedno z kritérií při príijímání studentů. Vztah jejich výsledků a výsledků studia na VŠ zkoumá studie College Board z roku 2009 (Mattern, Shaw \& Xiong, 2009), ve které se počet studentů pohybuje mezi 71377 (biologie) a 93775 (americká historie). Tato studie dokazuje, že lepší výsledky z AP předmětů angličtina, biologie, ma- tematika a americká historie korespondují $s$ lepšími průměrnými známkami v prvním ročníku VŠ, postupem do druhého ročníku a studiem na více selektivních vysokých školách. Výsledky také naznačují, že studenti, kteří dělají AP zkoušky, jsou lépe připraveni na náročné studium na vysokých školách. I středoškolské výsledky, potažmo středoškolský průměr známek (HSGPA), jsou považovány za konzistentně nejlepší prediktor jak bodového průměru v prvním roce studia $(\mathrm{r}=0,31)$, tak i bodového průměru za celé studium $(r=0,34)$ (Geiser \& Santelices, 2007). Predikční váha středoškolských známek vzrostla ještě po prvním roce studia a autoři docházejí k závěru, že by vysoké školy měly na středoškolské známky brát mnohem větší ohled.

Sočan et al. (2016) zjištovali predikční validitu slovinské maturity, která funguje na obdobném principu jako maturita česká, tj. jedná se o jednotnou národní zkoušku povinnou pro všechny studenty středoškolského vzdělávání. Kromě této funkce je slovinská maturita využívána také jako nástroj pro príijímání na vysoké školy. V tomto výzkumu byla využita data 1734 studentů filozofické fakulty a úspěšnost byla měřena $\mathrm{z}$ hlediska známkového průměru a dokončení studia v řádné době. Maturita se ukázala být důležitým prediktorem akademického úspěchu, ve zmiňované studii dokázala samotná maturita vysvětlit okolo $37 \%$ variability průměr-

\footnotetext{
${ }^{6}$ Jedná se o nejprestižnější britské univerzity, např. Oxford a Cambridge.

${ }^{7}$ International Baccalauréat je mezinárodní maturitní zkouška, Cambridge Pre-U a BTEC jsou alternativy A-Levels, kdy BTEC je více odborně zaměřnou zkouškou. U Extended Project se jedná o samostatnou práci studenta, kterou lze přibrat k závěrečným zkouškám.
} 
ných známek, což bylo více, než dokázaly vysvětlit samotné středoškolské známky v posledním roce studia (22\%). V potaz přitom bylo vzato hierarchické uspořádání dat. Úroveň predikční validity byla srovnatelná např́ić analyzovanými studijními programy.

Predikční validitu maturitní zkoušky zkoumal také Rasmus (2016) ve Finsku, pracoval ale $s$ mnohem menším vzorkem studentů a i metodologicky byla jeho práce omezenější, nebrala např̀ $v$ potaz hierarchické uspořádání $\mathrm{v}$ rámci studijních programů. Práce analyzovala výsledky 50 studentů humanitních i prírodovědných oborů. Kromě maturitní zkoušky zjištoval autor také validitu přijímací zkoušky a inteligenčního testu používaného při přijímacím řízení. Kritériem úspěšnosti byl průměr známek během prvního roku studia (FYGPA), počet kreditů a jejich kombinace. Maturitní zkouška významně predikovala FYGPA $(r=0,51)$, inteligenční test měl jen slabý vztah s celkovým FYGPA, koreloval však $s$ výsledky $\mathrm{v}$ některých předmětech. Analýza neprokázala korelaci FYGPA s přijímací zkouškou, což bylo nejspíše způsobeno různým obsahem a obtížností príijímací zkoušky pro různé obory.

\section{PredikČní Validita PŘIjímacích TESTU゚ V USA}

Nejvíce validizačních studií přijímacích testů na vysoké školy pochází z USA a zabývají se především SAT testy, které spolu s testy ACT využívá většina vysokoškolských institucí $\mathrm{v}$ prìijímacím řízení pro výběr studentů $s$ nejlepšími studijními předpoklady. SAT test se skládá ze tří částí (čtení, matematika a psaní) a dále mohou studenti skládat také př̀edmětové testy, tzv. subject tests, které pokrývají pět oblastí - matematiku, př́rodovědné předměty, angličtinu, historii a cizí jazyky. Většina těchto studií vznikla v neziskové organizaci College Board, která tyto testy vytváríi. Kobrin et al. (2008) se zabývali validitou SAT testu pro předpověd' průměru známek v prvním ročníku na vysoké škole. Autoři pracovali s daty za školní rok 2006/2007, vzorek zahrnoval 151316 studentů ze 110 škol a jako odhad míry validity použili koeficient korelace. Součástí jejich měření byly nejen výsledky SAT za rok 2006, ale také průměr známek na střední škole. Nejvyšší predikční validita byla zjištěna u části Psaní a nejlepším prediktorem se ukázala být kombinace SAT skóre a průměru známek na střední škole. Korelační koeficienty lineární kombinace SAT skóre a známek ze střední školy se pohybovaly v rozmezí $\mathrm{r}=0,44-0,52$, zatímco samotná korelace SAT byla $\mathrm{r}=0,34-0,42$ a u středoškolského prospěchu vycházela $r=0,35-0,41$. $\mathrm{Z}$ toho důvodu College Board dle autorů doporučuje používat oba parametry při přijímání studentů.

K podobným závěrům docházejí i starši studie. Přehledová práce Burtona a Ramista (2001), která mapuje práce zabývající se predikční validitou SAT od roku 1980 do poloviny devadesátých let 20 . století, uvádí, že výsledky většiny prací dokazují, že nejlepšími prediktory akademického úspěchu nejsou samotné SAT testy, ale jejich kombinace se středoškolskými známkami. 
Jedním z častých kritérií akademického úspěchu je také postup do druhého ročníku na vysoké škole. Schopnost SAT predikovat toto kritérium ověrovali Mattern a Patterson (2009). Ti pracovali se vzorkem 147999 studentů ze 106 univerzit. Ze studentů s nejvyšším SAT skóre do druhého ročníku nastoupilo $95,5 \%$, zatímco z těch s nejnižším skóre jen 63,8\%. Podobný vztah platil i pro průměr známek na střední škole jako prediktorem postupu do druhého ročníku.

Další práce pochází z roku 2006 a jejím tématem je schopnost SAT předpovídat různé stupně úspěchu při studiu (Kobrin \& Michel, 2006). Při této analýze byly použity vzorky z 30 vysokých škol a zahrnovaly 34000 studentů, přičemž vzorek měl vyšši průměrné SAT skóre, než je národní průměr. $\mathrm{V}$ analýze bylo zvlášt analyzováno šest skupin dle FYGPA a porovnány byly vždy tři různé logistické modely pro predikci úspěšnosti studia: model obsahující pouze SAT jako vysvětlující proměnnou, model obsahující pouze HSGPA a model obsahující kombinaci obou proměnných. Autoři dospěli k závěru, že model obsahující pouze SAT je v predikci úspěšnosti jen o málo přesnější než model obsahující pouze průměr známek na střední škole. Dále bylo v této studii zjištěno, že pro studenty z méně selektivních škol je lepším prediktorem úspěchu průměr známek na střední škole. Celkově se ukázalo, že SAT př́edpovídá lépe úspěšnost studentů s vyšším FYGPA a průměr známek na střední škole dokáže lépe předpovědět neúspěšné studenty. Pro skupinu studentů $s$ nejvyšším průměrem známek v prvním ročníku vysoké školy $\mathrm{k}$ předpovězení míry úspěšnosti již dále nepřispěje ani SAT, ani průměr známek na střední škole.

\section{PrediKČNí VALIDITA PŘIJíMACÍCH TESTU゚ V DALŠíCH ANGLOSASKÝCH A EVROPSKÝCH ZEMÍCH}

Jak již bylo pojednáno výše, ve Velké Británii univerzity pro přijetí studentů primárně využívají A-Levels či akademický prospěch na střední škole. Jelikož A-Levels špatně rozlišují mezi nejlepšími studenty, na lékařských fakultách, kde je výběr velmi kompetitivní, jsou navíc hojně využívány testy studijních předpokladů a lékařského profesního chování. Dvěma nejvíce využívanými testy tohoto druhu jsou UK Clinical Aptitude Test (UKCAT) a BMAT. Zatímco Lynch, MacKenzie et al. (2009) nepotvrdili schopnost testu UKCAT predikovat prospěch v prvním ročníku, jeho predikční validita je prokázána v komplexních pracích McManus et al. (2013a, 2013b, 2013c). Autoři v nich dokládají schopnost UKCAT predikovat průměrný prospěch v prvním ročníku, celkový prospěch, i to, zda se student později objeví v registru specialistů. Je také prokázána jeho inkrementální predikční validita vzhledem k A-Levels, avšak predikční síla A-Levels je značně vyšší. Predikční validita testu BMAT byla prověrována např. ve studii Emery a Bell (2009, viz také McMannus et al., 2011). Autoři zde ukazují, že část tohoto testu zaměřená na znalosti silněji koreluje s pozdějším studijním prospěchem než část testující studijní předpoklady. 
Na Novém Zélandu se na lékařských školách používá UMAT test (Undergraduate Medicine and Health Science Admission Test) a ze studie, která porovnávala predikční validitu tohoto testu a středoškolských známek vyplývá, že UMAT vykazuje menší schopnost predikovat akademický úspěch v porovnání se známkami (Poole et al., 2012), kombinace obou kritérií predikční sílu vylepšila. Tento test je používán také v Austrálii, kde byla zjištována jeho predikční validita pro studijní bodový průměr. Korelační koeficient dosahoval hodnoty 0,15 , přričemž největší predikční sílu bylo možné přisoudit části 1 zaměřené na logické uvažování (Wilkinson, Zhang \& Parker, 2011).

Irská retrospektivní studie (Halpenny et al., 2010) menšího rozsahu (pouze 56 respondentů) se zaměrila na porovnání predikční validity přijímacího testu HPAT (Health Professions Admission Test) a závěrečných zkoušek na střední škole. Studie potvrdila, že oba tyto prediktory dokáží vypovídat o studijním úspěchu, prričemž korelace mezi nimi prokázána nebyla. Významnou predikční validitu lze nalézt i u přijímacího testu použivaného ve Švýcarsku (Cerutti, Bernheim \& van Gessel, 2013). Kritériem bylo zvládnutí zkoušek během prvního ročníku studia, které test signifikantně predikoval, a průměr $\mathrm{z}$ vybraných zkoušek $\mathrm{v}$ prvním roce studia, kde korelace dosáhla hodnoty 0,47 . Vysoká korelace může souviset se skutečností, že ke studiu byli přijati a do studie zahrnuti i studenti s nízkým skóre. Kadmon a Kadmon (2016) porovnávali predikční validitu přijímacího testu na lékařské fa- kulty v Německu, tzv. TMS test (Test for Medical Studies) a středoškolských výsledků. Ve všech studovaných skupinách byla predikční schopnost TMS přesvědčivější než predikční schopnost střredoškolských známek. Nedokončení studia silně souviselo $s$ faktem, zda student test zvládl složit, či nikoli. Ze studie vyplývá, že TMS je důležitým doplňkem přijímacího procesu a u skupin $s$ nízkým nebo vysokým středoškolským prospěchem může napomoci správně predikovat budoucí úspěšnost studentů.

\section{PredikČní VAlidita PŘIjímaCích TESTŮ V ČR}

V České republice byla v rámci mezifakultního projektu zjištována predikční validita přijímacích testů na Univerzitu Karlovu (Kolářová et al., 2004). Do studie byly zapojeny fakulty Filozofická (FF), Tělesné výchovy a sportu (FTVS), Matematicko-fyzikální (MFF), Pedagogická (PedF) a Prrírodovědecká (PřF). Shodně byl použit prediktor celkový počet bodů u príjímací zkoušky a kritériem byl průměrný prospěch v prvním ročníku studia. Nejvyšší absolutní hodnota korelačního koeficientu byla na MFF a PřF $-0,44$ a $-0,46$. Autoři si toto vysvětlují rozdílnou strukturou přijímacích zkoušek, kdy na MFF i PřF jsou shodné předměty $\mathrm{v}$ přijímací zkoušce a během prvního ročníku, zatímco např̀. na FTVS se přijímací zkouška skládá i z talentové části, testu studijních předpokladů a testu logického myšlení. Obsahová souvislost mezi přijímací zkouškou a tím, co je hodnoceno v prvním ročníku, je tedy 
na těchto fakultách podstatně větší než na FTVS. Komplexnějšš analýzu predikční validity príímacích zkoušek na MFF UK pomocí modelu logistické regrese provedli na datech z let 1995-1997 Zvára a Anděl (2001).

Filozofická fakulta Univerzity Palackého využívá $\mathrm{v}$ rámci svého přijímacího řízení test předpokladů ke studiu, jehož reliabilitu a validitu zjištovala Viktorová (2014) ve své diplomové práci a $\mathrm{k}$ dispozici měla údaje celkem 2581 studentů. Autorka pracovala se studijním průměrem studentů v prvním ročníku na vysoké škole a zjištovala jeho korelaci jak $s$ výsledky přijímacího testu, tak se známkami na maturitním vysvědčení, pokud tyto byly k dispozici. Pro rok 2011/2012 vychází Pearsonova korelace testu předpokladů ke studiu $r=-0,10$, pro rok 2012/2013 $r=-0,26$. Co se týče maturitních známek, jejich korelace se známkami v prvním roce studia je $r=0,25$ a 0,29 . Autorka se pozastavuje nad nízkou korelací prijímacího testu v roce 2011/2012 a jako jedno z možných vysvětlení nabízí fakt, že ten rok byl tento test, který si vytvořila sama škola, použit poprvé a jeho tvưrci tak ještě možná nevybrali nejlépe odpovídající obsahové položky. Dále poukazuje na vysoké hodnoty korelace u maturitního průměru a dodává, že $\mathrm{v}$ modelech bez oborového testu byl dokonce lepším prediktorem než test předpokladů ke studiu.

České vysoké školy využívají hojně testu studijních předpokladů od společnosti Scio (OSP) a studie, kterou vypracovali Synek a Otřísal (2008), se jako první zabývá výpočty predikční validity tohoto testu.
Pracovali s údaji ze tří fakult, a to Fakulty sociálních studií Masarykovy univerzity, Fakulty zdravotně sociální Ostravské univerzity a Vysoké školy chemicko-technologické. $\mathrm{Z}$ výsledků vyplývá, že test OSP lépe predikuje prospěch $\mathrm{v}$ prvním roční$\mathrm{ku}(\mathrm{r}=-0,41$, kde tedy vysvětlí přibližně $16 \%$ variability dat), zatímco schopnost predikovat výsledky ve druhém ročníku je menší $(r=-0,19)$. Co se týče jednotlivých částí testu, jejich korelace se pohybují mezi $-0,31$ a $-0,38$ v prvním ročníku, v druhém ročníku dosahují pouze hodnot $\mathrm{r}=-0,15$ a $\mathrm{r}=-0,16$. Lepším prediktorem je tedy výsledek celkového testu. Co se týče studijních oborů, test OSP lépe předpovídá úspěch studentů přírodních věd než věd společenských. U studentů VŠCHT měli autoři také informace o jejich středoškolském prospěchu (byt text bliže nespecifikuje, o jaké roky či předměty se jedná) a došli k závěru, že korelace mezi středoškolským prospěchem a prospěchem v prvním ročníku na vysoké škole je velmi slabá. Své výsledky porovnávali s údaji z meta-analýzy GRE testu (Kuncel et al., 2001) a zatímco korelace obou testů s prospěchem v prvním ročníku jsou přibližně stejné, v ostatních kritériích vychází korelace v české studii jako slabší.

Několik prací studuje současně predikční validitu přijímacích testů a středoškolských známek, potažmo závěrečných zkoušek. První dva zmíněné prediktory převažují v naprosté většině studií, z ostatních se vyskytují např. ústní pohovory, motivační eseje apod. Höschl a Kožený (1997) zjištovali predikční validitu přijímacích zkoušek na 3. lékařskou fakultu 
UK včetně známek ze střední školy a výsledků zkoušek během prvních tř́i ročníků studia. Autoři došli k závěru, že statisticky významný vliv mají výsledky přijímací zkoušky z fyziky, středoškolské známky z fyziky, motivace ke studiu medicíny hodnocená komisí a osobnostní dotazník. Závislostí na těchto prediktorech se podařilo vysvětlit $32 \%$ variability dosaženého známkového průměru.

Souvislost mezi středoškolským prospěchem, přijímacími zkouškami a vysokoškolským studiem zjištovala také Rubešová (2009). Její analýza se týkala studentů Př́rodovědecké fakulty UK, kteří se zapsali ke studiu v letech 2003-2005, a výsledky porovnávala $s$ dřivějšími studiemi. Mezi ně patři např́klad disertační práce Škaloudové (2003, in Rubešová, 2009), která analyzovala data o studentech Pedagogické fakulty UK. Kritériem úspěšného studia pro ni byl průměrný prospěch na VŠ, včetně počtu zkoušek i opravných termínů. Z jejích výsledků vyplývá, že středoškolský prospěch je stejně dobrý prediktor studijních úspěchů jako přijímací zkoušky, a v některých oborech se ukazuje být dokonce lepším prediktorem. $V$ průběhu studia se navíc jeho vliv snižuje pomaleji než vliv výsledku přijímacího řízení (Škaloudová in Rubešová 2009). Podle analýzy Rubešové dosahuje korelačního koeficient hodnoty $r=0,69$, což svědčí o značně velkém vlivu. $\mathrm{V}$ reakci na tyto výsledky autorka rozporuje časté tvrzení o neobjektivitě středoškolských známek a jejich vzájemné neporovnatelnosti, z čehož mnozí vyvozují, že prospěch ze střední školy nemůže kvalitně predikovat studijní úspěchy na vysoké škole. Při znalosti více informací, tedy jak prospěchu ze střední školy, tak výsledku príijímacích zkoušek, použila pro výpočet metodu mnohonásobné lineární regrese a výpočty ukázaly, že oba tyto faktory mají na průměr známek na vysokou školu nezastupitelný vliv.

Štuka et al. (2012) se zajímali o predikční validitu přijímacích testů a středoškolských známek na 1 . lékařské fakultě UK a z jejich závěrů vyplývá, že oba tyto prediktory samostatně vysvětlí zhruba podobné procento variability (okolo 15\%) celkového úspěchu, který byl zde definován jako úspěšné absolvování do sedmi let. Kombinace přijímacích zkoušek a středoškolského prospěchu pak vysvětlí až $22 \%$ variability a v kombinaci $s$ dalšími kritérii dokonce $31 \%$ variability celkové úspěšnosti. Autoři argumentují, že přijímací zkouška a středoškolský prospěch popisují jiné aspekty schopností studentů. Zatímco středoškolské známky vypovídají o dlouhodobějším studijním úspěchu a schopnosti uspět v široké škále předmětů, přijímací testy jsou úzce zaměřené a zjištují schopnosti studentů naučit se poměrně velké množství informací za určitý časový úsek, což je pro ně stěžejní při studiu medicíny. Současné využití jak středoškolských známek, tak i výsledku přijímacího testu by tedy mělo zvýšit kvalitu výběru potenciálních studentů.

\section{PredikČní Validita PŘijímacích TESTŮ DO NAVAZUJÍCÍHO STUDIA}

Jedním z často užívaných testů pro prijímání studentů do navazujících stu- 
dijních programů je test Graduate Record Examination (GRE) vyvíjený americkou neziskovou organizací Educational Testing Service. Tento test hodnotí verbální, kvantitativní a analytické schopnosti uchazečů o studium a využívají ho vysoké školy v mnoha zemích. Podobně jako SAT má i GRE test své oborové testy. Jednou z často citovaných prací na téma predikční validity GRE testu je studie Kuncela et al. (2001). Autoři v ní provedli rozsáhlou meta-analýzu jednotlivých částí GRE testu a vypočítali jejich korelace $s$ průměrem známek v prvním ročníku i se známkami za celé navazující studium. Dalšími kritérii byla doba $\mathrm{k}$ dosažení titulu, počet vydaných článků či vědecká činnost. Všechny části testu se ukázaly být dobrými prediktory jak známek $\mathrm{v}$ prvním ročníku, tak známek v celém navazujícím studiu (korelační koeficienty se pohybovaly $\mathrm{v}$ rozpětí od 0,32 do 0,50$)$, nejlépe ve všech oblastech vycházely ovšem testy oborové. Schopnost testu GRE předpovídat studijní úspěchy potvrzují i Burton a Wang (2005), kteř́ se zaměřili na kvantitativní a verbální část testu a spolu $s$ nimi zjištovali predikční validitu studijního průměru v předchozím studiu. Při kombinací všech těchto tří prediktorů dosahovala korelace $s$ průměrným prospěchem za studium hodnoty 0,49 . Studie provedená $\mathrm{v}$ rámci ETS (Young et al., 2014) zkoumá validitu GRE testu na ekonomických školách. Kritériem úspěšnosti zde byl studijní průměr za první semestr a studijní průměr za celé studium. $Z$ výsledků vyplývá, že GRE test vykazuje vysoký stupeň predikční validity, při pohledu na jeho jednotlivé části se ukazuje, že významný vliv mají především kvantitativní a verbální část. Korelace studijního průměru v předchozím studiu, což je kromě GRE testu jeden z hlavních prediktorů, je o něco nižší.

Budoucí studenti lékařských fakult musí v USA složit tzv. MCAT (Medical College Admission Test). Schopnost MCAT predikovat úspěšné dokončení studia byla analyzována ve studii zabývající se studenty 119 institucí, kteří skládali MCAT v letech 2001-2004 (Dunleavy et al., 2013). Autoři zde pomocí logistické regrese ukazují, že samotné MCAT i samotný studijní průměr $\mathrm{v}$ předchozím studiu predikují úspěšnost studia, přičemž predikční schopnost předchozího prospěchu byla o něco vyšší. Signifikantně lepších výsledků bylo dosaženo kombinací obou prediktorů. Naopak Salvatori (2001) ve své meta-analýze zahrnující 83 článků dospívá k závěru, že nejlepším samotným prediktorem studijního úspěchu je průměr známek $\mathrm{z}$ předchozího studia. Ten ovlivňuje $\mathrm{i}$ to, zda student své studium dokončí. I tato studie uzavírá, že MCAT je dobrým prediktorem, signifikantně lepších výsledků je dosaženo $v$ prŕpadě jeho kombinace s průměrem známek za předchozí studium.

\section{PredikČní VAlidita}

\section{STŘEDOŠKOLSKÉHO PROSPĚCHU}

\section{A PŘIJÍMACÍCH ZKOUŠEK}

\section{DALŠÍCH ZEMÍCH}

Zkoumání predikční validity přijímacích testů, závěrečných zkoušek nebo středoškolských známek je nesmírně důle- 
žité a přínosné pro vysoké školy, které mohou tyto informace využít pro zlepšování svých nástrojů použivaných pro přijímání nových studentů. Není tedy překvapivé, že validizační studie tohoto typu vznikají i v dalších zemích. Hattami z Jemenu (2012) došel ve své disertační práci k závěru, že jak středoškolský průměr, tak přijímací testy jsou významnými prediktory akademického úspěchu v podobě průměru známek během prvního ročníku i během celého studia. Dále jmenujme Zimbabwe a Etiopii, kde vznikly dvě práce posuzující predikční validitu středoškolských známek a přijímacích testů. To, že předchozí studijní výsledky z velké části ovlivňují vysokoškolské studium, potvrzují Adebayo a Dorcas (2014). Ti zkoumali vliv O-Levels a A-Levels na celkový studijní průměr studentů ekonomické školy. Vysokou korelaci vykazovaly zkoušky z matematiky (O-Levels) a účetnictví (A-Levels). Dalším posuzovaným prediktorem byl průměr předchozích známek, který dokázal vysvětlit až z 64,4\% budoucí studijní úspěchy. Tesfa (2014) zjištoval vliv středoškolských známek a prijímacích testů na průměr známek v prvním ročníku u oborů matematika, počítačové technologie, geologie a statistika. Oba prediktory byly shledány významnými, a to naprríč obory. Jejich kombinace dokázala vysvětlit úspěšnost v prvním ročníku z $59 \%$ u matematiky a přes $30 \%$ u počítačové technologie a statistiky. Brány jednotlivě, oba prediktory dokázaly předpovědět studijní úspěch na přibližně stejné úrovni, jen u geologie byl shledán jako o něco lepší prediktor středoškolský průměr.
$\mathrm{V}$ rámci Educational Testing Service byla vydána studie zabývající se predikční validitou GRE testu na singapurské univerzitě, která potvrzuje závěry ostatních prací a také dokládá, že GRE test, a především jeho kvantitativní část, je významným prediktorem úspěšného dokončení studia (Liu et al., 2016).

\section{DisKuSE}

Z výše citovaných studií vyplývá, že závěrečné zkoušky, přijímací testy i středoškolský prospěch mají své opodstatnění $\mathrm{v}$ rámci přijímacích řízení na vysoké školy. Pro všechny tyto prediktory nalezneme studie potvrzující jejich schopnost předpovědět vysokoškolský prospěch či úspěšné dokončení studia. Mnoho studií dochází $\mathrm{k}$ závěru, že signifikantně lépe predikuje kombinace těchto prediktorů než prediktory samotné. To je očekávatelný výsledek, když se jedná do jisté míry o nezávislé proměnné vypovídající též o odlišných schopnostech uchazečủ (např. dlouhodobé úsilí o dobrý středoškolský prospěch vs. krátkodobá a cílená intenzivní prríprava na přijímací testy).

Někteří autoři výslovně vyzdvihují predikční váhu středoškolských známek (Salvatori, 2001; Atkinson \& Geiser, 2009; Rubešová, 2009) a upozorňují také na fakt, že stř̌edoškolské známky jsou mnohem méně provázány se socioekonomickým zázemím studentů než přijímací testy, u nichž lze vytěžit z krátkodobé cílené (a často zpoplatněné) prŕípravy. Domníváme se však, že zvýšení váhy středoškolských známek $\mathrm{v}$ prrijímacím řízení by 
mohlo způsobit větší tlak na středoškolské pedagogy, aby svým studentům „zbytečně nekazili prospěch“. Tím by postupně došlo k oslabování predikční síly středoškolského prospěchu a prípadně $\mathrm{k}$ ještě větším rozdílům mezi uchazeči z různých škol a možné neférovosti $v$ príijímacím řízení způsobené různým př́stupem ke známkování na jednotlivých školách.

U přijímacích zkoušek tak do hry vstupuje rozporuplným způsobem téma spravedlivosti. $\mathrm{Na}$ jedné straně príijímací zkoušky vytvářejí pro všechny uchazeče srovnatelné podmínky, na straně druhé je výzkumně dokládáno (Atkinson \& Geiser, 2009), že výsledky v nich jsou do velké míry ovlivněny i socioekonomickým zázemím rodiny uchazeče.

Zkoušky zakončující středoškolské vzdělávání stojí z hlediska času uprostřed mezi průběžným středoškolským prospěchem a prijímacími zkouškami na vysokou školu. Jejich váha v rámci přijímacích řízení se odvíjí i od míry jejich standardizace, nakolik přinášejí pro vysoké školy informace spolehlivé a mezi středními školami srovnatelné. Nepřekvapí využívání takových zkoušek ve Velké Británii, kde je i systematicky sledována jejich predikční validita. V České republice má relativně vysokou míru standardizace společná část maturitní zkoušky. Zatím je povinná pouze zkouška z českého jazyka a literatury, dále mají žáci na výběr mezi matematikou a jedním ze šesti cizích jazyků. Vysoké školy se tedy nemohou při analýzách predikční validity „automaticky" spolehnout na prítomnost některých prediktorů. Přitom musí dávat dostatečně dopředu na vědomí, zda např. výsledek $\mathrm{z}$ testu $\mathrm{z}$ matematiky bude hrát nějakou roli a jakou $\mathrm{v}$ prijiímacím řízení, aby se mohli žáci na tuto zkoušku přihlásit, a hlavně již dřive déledobě připravovat. Navíc zkoušky z cizích jazyků jsou cíleně připravovány na úrovni B1 podle Společného evropského referenčního rámce pro jazyky, tzn. že zkouška je připravována jako ověrující na nízké úrovni a výsledky pak nedokáží dostatečně dobře diferencovat mezi vynikajícími uchazeči pro některé specifické obory vzdělávání. Tato specifika zkoušek pak výrazně ovlivňují jejich použitelnost jako prediktorů. Z hlediska koncepční přípravy je důležité si ujasnit, že cílem certifikační zkoušky uzavírající středoškolské vzdělávání s maturitou není dobře diferencovat žáky, proto nemusí řadě vysokých škol a specifických oborů vyhovovat jako užitečný zdroj informací v prrijímacím rrízení. Na druhou stranu jsou vysoké školy a obory, kde může i takto koncipovaná maturitní zkouška přinášet takové informace, které mají vysokou predikční validitu. $V$ každém prŕípadě je žádoucí, aby tyto validizační studie vznikaly, aby konkrétní vysoká škola, fakulta či obor znaly odpověd' na otázku, jaká je v př́padě jejího studia predikční validita maturitní zkoušky, jaká je optimální kombinace prediktorů v príijímacím řízení.

Dále je potřeba připomenout, že ač přijímací zkoušky a středoškolský prospěch dokáží velmi slušně předpovídat studijní úspěchy, velké procento variability studijních úspěchů zůstává nadále nevysvětlených (až $70 \%$ dle Atkinson \& Geiser, 2009). To lze vysvětlit tím, že studium ovlivňuje i spousta dalších faktorů jako 
motivace, sociální a finanční zázemí, studijní návyky apod. Je proto důležité hledat také způsoby jak měřit další, nekognitivní faktory, jako jsou zkušenosti, vyspělost, komunikační a interpersonální dovednosti, empatie a etická integrita (Salvatori, 2001). I z tohoto důvodu školy $\mathrm{v}$ príijímacím řízení zohledňují i další informace o uchazečích, jako jsou úspěchy v soutěžích, mimoškolní aktivity, využívány jsou osobní pohovory a motivační eseje. Predikční validitu těchto informací a metod je ale třeba také ověřovat. Zejména je potřeba ověrovat vhodnost kombinací informací a rozhodovacích postupů z hlediska jejich celkové predikční síly, z hlediska praktičnosti realizace, ale i spravedlivého prrístupu ke všem uchazečům.

V námi sledovaných studiích nabývala predikční validita hodnot $\mathrm{v}$ širokém rozsahu. Rozdíly mohou být způsobeny kritérii, vůči nimž se validita zkoumá. Nejčastěji hodnocená je schopnost předpovědět prospěch v prvním ročníku vysoké školy, která je sice nejlépe dostupným kritériem, měrí ale pouze provázanost prediktorů $s$ předměty vyučovanými $\mathrm{v}$ prvním roce (Koláŕová et al., 2004). Např́klad u oborových testů na lékařské fakulty pak může být schopnost predikovat FYGPA vyšší než schopnost predikovat celkovou úspěšnost, jejiž částí je i klinická část studia, nebo dokonce profesionální úspěšnost budoucích lékařů (McManus, 2013a). Schopnost vybírat budoucí schopné profesionály by však měla být pro společnost prioritou, omezení se na testy, které dobře předpoví FYGPA, z tohoto pohledu může být krátkozraké. Pozornost některých týmů (viz např. Ziv et al., 2008) se proto obrací $\mathrm{k}$ přesnějšímu hodnocení osobnostních rysů a interpersonálních kvalit pomocí inovativních hodnoticích center posuzujících např. také uchazečovu schopnost komunikace $s$ pacientem. Výsledky těchto príiímacích testů sice nemusí nutně korelovat $s$ úspěchem v prvních letech studia, prosejí však ze skupiny skupinu uchazečů, kteří mají přes výtečné výsledky v kognitivních testech malé předpoklady $\mathrm{k}$ úspěšnému výkonu lékařské profese.

\section{ZÁVĚR}

Tato přehledová studie připomíná, že úroveň predikční validity záleží na mnoha dalších aspektech a může být různá, je-li stejný test použit pro jiný studijní program, v jiné zemi či v závislosti na př́snosti výběrového procesu, obzvláště jsou-li analýzy prováděné pouze na skupině přijatých studentů. Všechny tyto aspekty mohou ovlivnit homogenitu sledovaného vzorku a následně pak ovlivnit sílu statistické závislosti mezi prediktorem a sledovaným kritériem úspěšnosti na vysoké škole. Výsledky jedné validizační studie nelze tedy paušálně převést do jiných podmínek, je tudíž důležité, aby jednotlivé vysoké školy prováděly své validizační studie, $\mathrm{v}$ nichž budou aspekty jejich prrijímacího řízení zohledněny.

Naše přehledová studie také ukazuje, že nejjednodušší statistické přístupy mnohdy nemusí stačit k prokázání validity, resp. mohou na nich být učiněny nesprávné závěry. Kvalitní validizační studie by měla být založena na reprezentativním vzorku 
dostatečné velikosti a zohlednit případné hierarchické uspořádání dat a další aspekty. Vedle korelace daného prijímacího testu $s$ kritériem by vždy měla být prokázána také jeho inkrementální predikční validita (McManus et al., 2011), tedy informační prrínos vedle dalších informací o uchazečích, které vstupují do procesu přijímacího řízení. Je třeba mít na zřeteli, že výsledky každé validizační studie jsou zobecnitelné pouze $\mathrm{v}$ daném oboru, za stejně postaveného výběrového řízení a na další obdobné vzorky uchazečů.

V této studii jsme se snažili představit spektrum validizačních studií, které mo- hou inspirovat také české vysoké školy. Přijímací řízení na vysoké školy je klíčovým momentem jak pro uchazeče, tak pro samotné vzdělávací instituce. Pravidelná validizace, analýza a ověrování kvality přijímacích testů by proto měla být samozřejmou součástí plánování a organizace přijímacích řízení. Rozšíření validizačních studií může dopomoci také dostupnost př́slušného analytického softwaru (viz např. Martinková, Drabinová \& Houdek, 2017). Věríme, že i tato přehledová studie přispěje $\mathrm{k}$ tomu, aby byly přijímací testy a přijímací řízení jako taková rutinně analyzovány i na českých vysokých školách.

\section{Literatura}

Adebayo, A. S., \& Dorcas, A. T. (2014). Entry criteria as predictor of academic success: A case of Solusi University, Zimbabwe. European Scientific Journal, 10(13).

Atkinson, R. C., \& Geiser, S. (2009). Reflections on a century of college admission tests. Research and Occasional Papers Series.

Burton, N. W., \& Ramist, L. (2001). Predicting success in college: SAT studie sof classes graduating since 1980. College Board Research Report 2001-2. New York: College Board.

Burton, N. W., \& Wang, M. (2005). Predicting long-term successin graduate school: A collaborative validity study. GRE Board Report No. 99-14R.

Cerutti, B., Bernheim, L., \& van Gessel, L. (2013). The predictive validity of the aptitude test for the performance of students starting a medical curriculum. Swiss Medical Weekly, 143, w13872.

Dunleavy, D. M., Kroopnick, M. H., Dowd, K. W., Searcy, C. A., \& Zhao, X. (2013). The predictive validity of the MCAT exam in relation to academic performance through medical school: A national cohort study of 2001-2004 matriculants. Academic Medicine, 88(5), 666-671.

Emery, J. L., \& Bell, J. F. (2009). The predictive validity of the BioMedical Admissions Test for pre-clinical examination performance. Medical Education, 43, 557-564.

Evans, B. J. (2015). College admission testing in America. In V. Stead (Ed.), International perspectives in higher education admission policy: A reader. New York: Peter Lang.

Geiser, S., \& Santelices, M. V. (2007). Validity of high-school grades in predicting student success beyond the freshman year. Research \& Occasional Paper Series. Center for Studies in Higher Education. USA, University of California. 
Gill, T., \& Vidal Rodeiro, C. L. (2014). Predictive validity of level 3 qualifications: Extended project, Cambridge Pre-U, International Baccalauréate, BTEC Diploma. Cambridge Assessment Research Report. Cambridge, UK: Cambridge Assessment.

Halpenny, D., Vadlo, K., Halpenny, M., Burke, J., \& Torreggiani, W. (2010). The health professions admission test (HPAT) score and leaving certificate results can independantly predict academic performance in medical school: Do we need both tests? Irish Medical Journal.

Hattami, A. A. D. (2012). Differential predictive validity of high school GPA and college entrance test scores for university students in Yemen. (Disertační práce).

HEFCE (2014). Differences in degree outcomes: Key findings. Dostupné z www.hefce.ac.uk/ media/hefce/content/pubs/2014/201403/HEFCE2014_03.pdf

Höschl, C., \& Kožený, J. (1997). Predicting academic performance of medical students: The first three years. American Journal of Psychiatry, 154(6, Suppl.), 87-92.

Kadmon, G., \& Kadmon, M. (2016). Academic performance of students with the highest and mediocre school-leaving grades: Does the aptitude Test for Medical Studies balance their prognoses? GMS Journal for Medical Education, 33(1).

Kobrin, J. L., Patterson, B. F., Shaw, E. J., Mattern, K. D., \& Barbuti, S. M. (2008). Validity of the SAT for predicting first-year college grade point average. College Board Research Report No. 2008-5. New York: College Board.

Kobrin, J. L., \& Michel, R. S. (2006). The SAT as a predictor of different levels of college performance. College Board Research Report No. 2006-3. New York: College Board.

Kolářová, R., et al. (2004). Stanovováni predikční validity didaktických testů použivaných při prijimacich zkouškách na UK. Praha: PedF UK. Výzkumná zpráva k projektu Zavádění nových metod do učitelského vzdělávání na Univerzitě Karlově.

Kuncel, N. R., Hezlett, S. A., \& Ones, D. S. (2001). A comprehensive meta-analysis of the predictive validity of the Graduate Record Examinations: Implications for graduate student selection and performance. Psychological Bulletin, 27(1), 162-181.

Liu, O. L., Kliner, D. M., Bochenek, J. L., Holtzman, S. L., \& Xu, J. (2016). An investigation of the use and predictive validity of scores from the GRE revised general test in a Singaporean university. ETS Research Report Series, 1, 1-12.

Lynch, B., MacKenzie, R., Dowell, J., Cleland, J., \& Prescott, G. (2009). Does the UKCAT predict year 1 performance in medical school? Medical Education 43(12), 1203-1209.

Martinková, P., Drabinová, A., \& Houdek, J. (2017). Shiny Item Analysis: Analýza přijímacích a jiných znalostních či psychologických testů. Testfórum, 9, 16-35.

Mattern, K. D., \& Patterson, B. F. (2009). Is performance on the SAT related to college retention? College Board Research Report No. 2009-7. New York: College Board.

Mattern, K. D., Shaw, E. J., \& Xiong, X. (2009). The relationship between AP Exam performance and college outcomes. College Board Research Report No. 2009-4. New York: College Board. 
McManus, I. C., Woolf, K., Dacre, J., Paice, E., \& Dewberry, C. (2013a). The Academic Backbone: Longitudinal continuities in educational achievement from secondary school and medical school to MRCP (UK) and the specialist register in UK medical students and doctors. BMC Medicine, 11(242).

McManus, I. C., Dewberry, C., Nicholson, S., \& Dowell, J. S. (2013b). The UKCAT-12 study: Educational attainment, aptitude test performance, demographic and socio-economic contextual factors as predictors of first year outcome in a cross-sectional collaborative study of 12 UK medical schools. BMC Medicine, 11(244).

McManus, I. C., Dewberry, C., Nicholson, S., Dowell, J. S., Wolf, K., \& Potts, H. W. W. (2013c). Construct-level predictive validity of educational attainment and intellectual aptitude tests in medical student selection: Meta-regression of six UK longitudinal studies. BMC Medicine.

McManus, I. C., Ferguson, E., Wakeford, R., Powis, D., \& James, D. (2011) Predictive validity of the Biomedical Admissions Test: an evaluation and case study. Medical Teacher, 33(1), 53-57.

McManus, I. C., Smithers, E., Partridge, P., Keeling, A., \& Fleming, P. R. (2003). A-levels and intelligence as predictors of medical careers in UK doctors: 20 years prospective study. BMJ, 327(139).

MŠMT (2017). Statistické výstupy a analýzy. Dostupné z http://www.msmt.cz/vzdelavani/skolstvi-v-cr/statistika-skolstvi/prijimaci-rizeni-ke-studiu-na-vysoke-a-vyssi-odborne-skole-1

NACAC (2016). Use of predictive validity studies to inform admission practices. NACAC Research Report. Dostupné z https://www.nacacnet.org/globalassets/documents/publications/research/testvalidity.pdf

Poole, P., Shulruf, B., Rudland, J., \& Wilkinson, T. (2012). Comparison of UMAT scores and GPA in prediction of performance in medical school: a national study. Medical Education, 46(2), 163-171.

Rasmus, J. (2016). Predicting study performance for one academic year at university. (Diplomová práce). Dostupné z http://www.mensa.fi/wordpress/wp-content/uploads/2016/05/Gradu-Jonathan-Rasmus.pdf

Rubešová, J. (2009). Souvisí úspěšnost studia na vysoké škole se středoškolským prospěchem? Pedagogická orientace, 3, 89-103.

Salvatori, P. (2001). Reliability and validity of admission tools used to select students for the health professions. Advances in Health Science, 6, 159-175.

Smith, J., \& Naylor, R. (2001). Determinants of degree performance in UK universities: a statistical analysis of the 1993 student cohort. Oxford Bulletin of Economics and Statistics, 63(1).

Smith, K. M. (2014). The predictive validity of pre-admission measures on podiatric medical school performance. (Disertační práce). Dostupné z http://digitalcommons.unl.edu/cgi/

Sočan, G., Krebl, M., Špeh, A., \& Kutin, A. (2016). Predictive validity of the Slovene Matura for academic achievement in humanities and social sciences. Horizont of Psychology, 25, 84-93. Synek, J., \& Otřísal, V. (2008). Predikčni validita testu OSP - výsledky analýzy. SCIO. 
Štuka, Č., Martinková, P., Zvára, K., \& Zvárová, J. (2012). The prediction and probability for successful completion in medical study based on tests and pre-admission grades. The New Educational Review, 28(2).

Tesfa, M. (2014). The validity of University Entrance Examination and high school grade point average for predicting first year university students' academic performance. University of Twente, Faculty of behavioural science.

Vidal Rodeiro, C. L., Sutch, T., \& Zanini, N. (2013). Prior learning of undergraduates in UK higher education institutions. Cambridge Assessment Research Report. Cambridge, UK: Cambridge Assessment.

Viktorová, L. (2014). Reliabilita a validita SPF (Test predpokladů ke studiu na FF UP). (Diplomová práce).

Wilkinson, D., Zhang, J., \& Parker, M. (2011). Predictive validity of the Undergraduate Medicine and Health Sciences Admission Test for medical students' academic performance. The Medical Journal of Australia, 194(7).

Young, J. W., Klieger, D., Bochenek, J., Li, C., \& Cline, F. (2014). The validity of scores from the GRE revised general test for forecasting performance in business schools: Phase one. ETS GRE Board Research Report No. RR-14-17.

Zanini, N., \& Vidal Rodeiro, C. L. (2014). The role of the $A^{*}$ grade at A-level as a predictor of university performance. Cambridge Assessment Research Report. Cambridge, UK: Cambridge Assessment.

Ziv, A., Rubin, O., Moshinsky, A., Gafni, N., Kotler, M., Dagan, Y., ... Mittelman, M. (2008). MOR: a simulation-based assessment centre for evaluating the personal and interpersonal qualities of medical school candidates. Medical Education, 42, 991-998.

Zvára, K., \& Anděl, J. (2001). Souvislost výsledků přijímacího řízení s úspěšností studia na MFF. Pokroky matematiky, fyziky a astronomie, 46(6), 304-312.

Mgr. Irena Bartáková

Ústav výzkumu a rozvoje vzdèláváni, Pedagogická fakulta Univerzity Karlovy;

e-mail:irabartakova@email.cz

PhDr. Martin Chvál, Ph.D.

Ústav výzkumu a rozvoje vzděláváni, Pedagogická fakulta Univerzity Karlovy;

e-mail: martin.chval@pedf.cuni.cz

RNDr. Patrícia Martinková, Ph.D.

Oddèleni statistického modelováni, Ústav informatiky $A V C \check{C}$,

Ústav výzkumu a rozvoje vzdělávání, Pedagogická fakulta Univerzity Karlovy;

e-mail:martinkova@cs.cas.cz,patricia.martinkova@pedf.cuni.cz 


\section{THE PREDICTIVE VALIDITY OF SCHOOL LEAVING EXAMINATIONS AND UNIVERSITY ENTRANCE TESTS}

\section{Irena Bartáková, Martin Chvál, Patrícia Martinková}

This review study gives an overview of selected studies of the predictive validity of final secondary-school examinations and university entrance tests. Predictive validity is an important property of tests, expressing their capacity to predict future success. University entrance test scores and secondary-school grade point average (GPA) are among the most frequently used predictors, and comparison of their influence is an often discussed topic. Although there exist several criteria for academic success, the most often applied outcome measures are first-year university GPA, successful progress to the second year, or successful completion of university degree. The studies analyzed in the article are divided into categories according to their main goal, from studies focused on secondary-school examinations to studies of the predictive validity of university entrance tests. Another criterion for classification is the country of origin of the data. A separate section is devoted to studies conducted in the Czech Republic. It clearly emerges from the studies that the use of both entrance test scores and secondary-school GPA as admission criteria are justified. Both these parameters predict whether the student will be successful in studies and will obtain university degree, while the best results in terms of predictive power are usually achieved by the use of both parameters together.

Keywords: predictive value, secondary-school grade point average, entrance tests, predictor, academic success university grade point average. 